\title{
Soil Application of Bacillus thuringiensis Berliner Isolates against Root-Knot Nematode (Meloidogyne javanica (Treub) Chitwood) in Okra (Abelmoschus esculentus (L.) Moench)
}

\author{
M. W. ABBASI ${ }^{1}$, M. Q. KHAN ${ }^{1}$, M. J. ZAKI ${ }^{1}$, S. S. SHAUKAT ${ }^{1}$, A. RAUF ${ }^{1}$, \\ N. AHMED ${ }^{1}, \mathrm{M} \cdot \mathrm{AZEEM}^{1}$ and M. TARIQ ${ }^{2}$ \\ ${ }^{1}$ Department of Botany, ${ }^{2}$ MAHQ Biological Research Centre, University of Karachi, Karachi-75270, Pakistan
}

(Received: 7 January 2019; accepted: 11 March 2019)

\begin{abstract}
Bacillus thuringiensis (B.t) is well known for its biocontrol potential against a variety of insects. Nematicidal potential of ten B.t isolates was tested against root-knot nematodes (Meloidogyne javanica (Treub) Chitwood) in vitro, under greenhouse as well as in field conditions. Eggs and second stage juveniles (J2) were exposed to 5 and $25 \%$ concentrations of bacterial cell-free aqueous extracts up to 96 h. B.t isolates showed lesser degrees of nematicidal activity at 5\% concentration. However, some B.t isolates (B.t-14, B.t-16 and B.t-64) greatly reduced egg hatching and increased J2. All B.t isolates revealed suppressed egg hatching and increased mortality of $\mathrm{J} 2$ at $25 \%$ concentration. Soil applications with most of the B.t isolates under greenhouse and field conditions significantly improved height and fresh weights of root-knot nematode parasitized okra (Abelmoschus esculentus (L.) Moench). Some isolates, including B.t-64 reduced the number of galls and egg masses. B.t-64 reduced gall formation up to $70 \%$ under greenhouse conditions. However, $29 \%$ of decrease was observed in field conditions. Similarly, B.t-64 treated plants showed a 56\% decreased in eggs/egg mass in a field experiment. Population of root-knot nematodes in the rhizosphere was decreased up to $61 \%$ in the field experiment as compared to control.
\end{abstract}

Keywords: Biocontrol, Bacillus thuringiensis, nematodes, okra, soil drench.

Bacillus thuringiensis Berliner, a Gram-positive spore forming bacterium is widely distributed in the environment and has been isolated from soil, water samples, insects and leaves of deciduous and coniferous trees (Bernhard et al., 1997; Mizuki et al., 1999; Hill et al., 2004; Vilas-Bôas and Lemos, 2004). B. thuringiensis is capable of producing crystal proteins during sporulation phase known as delta-endotoxins. These crystal proteins are specific to a wide variety of insects and pests (Vilas-Bôas et al., 2000). Root-knot nematodes Meloidogyne species are known to attack a wide range of economically important crops, including vegetables and cause severe yield losses in tropical and sub-tropical agriculture (Luc et al., 2005). Application of microorganisms antagonistic to root-knot nematodes or compounds produced by these microbes such as antibiotics, siderophores and enzymes could provide an additional opportunity for managing the damage caused 
by root-knot nematodes. Bacillus species are reported to contain more than $8.5 \%$ of the genome that is devoted to synthesizing antibiotics and siderophores to compete with other microorganisms in rhizosphere (Chen et al., 2007). There are several reports of nematicidal activities of several Bacillus species (Li et al., 2005; Yap, 2013; Adam et al., 2014; Flor-Peregrín et al., 2014). Production of metabolites by rhizosphere bacteria causes lysis of nematode eggs and reduces egg hatching in Heterodera schachtii (Oostendorp and Sikora, 1990). Most of rhizobacteria act against plant-parasitic nematodes by means of metabolic by-products, enzymes and toxins. The effects of these toxins include the suppression of nematode reproduction, egg hatching and juvenile mortality and survival of nematodes (Siddiqui and Mahmood, 1999). Many isolates of B. thuringiensis have been used as biological control agents against root-knot nematodes (Zuckerman et al., 1993; Wei et al., 2003; Dhawan et al., 2004; Mohammed et al., 2008; Khan et al., 2010).

Okra (Abelmoschus esculentus (L.) Moench) considers as an important vegetable crop rich in proteins and edible oil. Mucilage in fruits comprised pectin and carbohydrates. Root-knot nematodes consider as a major threat of okra. A study revealed that Meloidogyne species prevailed in $85.28 \%$ of okra fields in Punjab province of Pakistan with an average incidence of $38.89 \%$ (Hussain et al., 2012). This study was designed to assess B.t isolates against Meloidogyne javanica (Treub) Chitwood in the greenhouse as well as field conditions in okra. Lower concentrations of cell free extracts of B.t isolates were also tested to assess mortality of $\mathrm{J} 2$ and hatching of eggs. As far as we know, no detailed study was conducted to evaluate the potential of number of B.t isolates in soil against root-knot nematodes in sub-tropical regions of the world.

\section{Materials and Methods}

\section{Bacterial cultures}

Bacillus thuringiensis (B.t) strains previously isolated from rhizosphere of different crops (okra, brinjal, cotton, tomato, onion, cabbage and watermelon crops) around the Sindh province of Pakistan (Khan et al., 2010). Identified bacterial cultures were grown in Luria-Bertani broth for $24 \mathrm{~h}$ and stored in $20 \%$ glycerol at $-80{ }^{\circ} \mathrm{C}$. B.t isolates were grown in Luria-Bertani broth at $37^{\circ} \mathrm{C}$ for $48 \mathrm{~h}$ in shaking incubator $(120 \mathrm{rpm})$ in dark and centrifuged twice at $716 \mathrm{~g}$ for $20 \mathrm{~min}$. The pellets and supernatants were separated. Pellets were re-suspended in sterilized distilled water and density of the suspension was maintained to $10^{9}$ cells $/ \mathrm{ml}$ for greenhouse experiment and $10^{11}$ cell $/ \mathrm{ml}$ for field experiment. Supernatants (culture filtrate) were collected in sterilized capped bottles before use. Different concentrations ( 5 and $25 \%$ ) of bacterial culture filtrate were prepared by adding sterile distilled water for in vitro studies. B.t endotoxins are well known for nematicidal activity (Bottjer et al., 1985; Payne, 1992; Wei et al., 2003). However, the nematicidal potential of B.t exotoxins were not well documented. That is the reason behind this study to assess the nematicidal potential of B.t exotoxins. 


\section{Root-knot nematode culture}

Root-knot nematode species were identified in the laboratory by observing the perennial pattern in adult females as described by Taylor and Netscher (1974). Root-knot nematodes were identified as Meloidogyne javanica (Treub) Chitwood. The root-knot nematodes were cultured on eggplant seedlings in pots containing autoclaved soil under greenhouse conditions from a single egg mass.

\section{In vitro nematicidal activities}

\section{Hatching of juveniles}

Eggs of M. javanica were obtained as described by Hussey and Barker (1973). A suspension of eggs was prepared in sterilized distilled water. Thereafter, $100 \mu 1$ of egg suspension (40-70 eggs) was transferred to each glass cavity block ( $4 \mathrm{ml}$ final volume) of different concentrations of cell free filtrate (final concentration maintained at 5 or $25 \%$ ) and kept at room temperature $\left(25 \pm 2{ }^{\circ} \mathrm{C}\right)$. After $24,48,72$ and $96 \mathrm{~h}$, number of hatched juveniles were counted under a low power $(\times 6)$ stereomicroscope. The toxicity of filtrate was assessed on the basis of mean percentage of the hatched eggs (Cayrol et al., 1989). Each treatment was replicated six times. Glass cavity blocks with $4 \mathrm{ml}$ sterile water served as control.

\section{Mortality of J2 of M. javanica}

Parasitized roots of eggplant (Solanum melongena L.) were collected and washed thoroughly with distilled sterilized water before use in the bioassay to avoid other microbes. Egg masses of $M$. javanica were collected from the roots with the help of a needle under stereomicroscope, placed in sterile distilled water and incubated at room temperature for 48 h. Roots were washed. After hatching, the juveniles were collected and a suspension of juveniles was prepared in sterile distilled water. Subsequently, $100 \mu 1$ suspension of J2 (35-55) was added to all replicates of each concentration of cell free filtrate. After 24, 48, 72 and 96 h exposure, numbers of dead juveniles were counted. The toxicity of filtrate was assessed on the basis of mean percentage of the dead juveniles. Nematodes were considered dead if they did not move when probed with a fine needle (Cayrol et al., 1989). Other conditions of mortality assay as described in hatching section.

\section{Greenhouse studies}

Sandy clay loam soil was obtained from an experimental field of the Department of Botany, University of Karachi. Five seeds of okra Abelmoschus esculentus (L.) Moench cv. OH-152 were sown in each plastic pot ( $8 \mathrm{~cm}$ diameter) containing $300 \mathrm{~g}$ of soil. One week after seedling emergence (seeds start to emerge from day three, however, we considered when maximum emergence was obtained at day seven), two seedlings were maintained in each pot and seedlings were drenched with $20 \mathrm{ml}$ of bacterial cell suspension $\left(9 \times 10^{9}\right.$ cells $\left./ \mathrm{ml}\right)$. In controls $20 \mathrm{ml}$ sterile distilled water was used for drenching. The second day after bacterial application, each pot was inoculated with $2000 \mathrm{~J} 2$ of root-knot nematode $M$. javanica. Pots were randomized on a greenhouse bench. Observations on 
plant growth parameters and root-knot nematode parasitism were recorded after 45 days of nematode inoculation. The experiment was repeated to find variability in the observations. However, the variance between the repeated experiments were closely similar; therefore, the analysis was performed on pooled replicates.

Plant growth parameters including shoot lengths, shoot weights, root lengths and root weights were recorded immediately after harvesting. Galls and egg masses on roots were counted under stereomicroscope $(\times 6)$. Egg masses were stained with $0.015 \%$ Phloxine B for 20 minutes before counting (Daykin and Hussey, 1985). Number of eggs per egg mass were counted in 10 egg masses that were randomly collected from each root and treated with $2 \% \mathrm{NaOCl}$ for 2 minutes (Hussey and Barker, 1973). Released eggs were collected in 400 mesh sieve and $10 \mathrm{ml}$ egg suspension was prepared with distilled water. Eggs were counted under a compound microscope (10X). Root-knot nematode population in rhizosphere was determined by modified Bearmann funnel technique (Townshend, 1962).

\section{Field studies}

Seeds of okra were sown in $2 \times 1$ meter micro plots at experimental field of Department of Botany, University of Karachi, according to the randomized complete block design. After one week of seedling emergence the seedlings were drenched with cell suspension of actively growing cultures of B. thuringiensis isolates B.t-64 $\left(5.5 \times 10^{11} \mathrm{CFU} \mathrm{ml}^{-1}\right)$, B.t $14\left(5.15 \times 10^{11} \mathrm{CFU} \mathrm{ml}{ }^{-1}\right)$ and B.t-16 $\left(3.8 \times 10^{11} \mathrm{CFU} \mathrm{ml}^{-1}\right) 300 \mathrm{ml}$ per meter of row. Seedlings drenched with sterile distilled water were kept as control. Second day of bacterial application, the seedling rows were then inoculated with $12000 \mathrm{~J} 2$ of root-knot nematode. Experiments were conducted twice with similar protocols. Plant growth and nematode parasitism by counting number of galls/root system and egg masses/root system were recorded two months after nematode inoculation.

\section{Analysis of data}

Data were analyzed for descriptive statistics and analysis of variance (ANOVA). The follow-up of ANOVA included calculation of Tukey's HSD to compare the treatment means (Gomez and Gomez, 1984).

\section{Results}

\section{Egg hatching of root-knot nematodes}

Cell free culture filtrate of different B. thuringiensis isolates, viz. B.t-6, B.t-7, B.t-8, B.t-9, B.t-10, B.t-13, B.t-14, B.t-15, B.t-16 and B.t-64 were tested at different concentrations (5\% and 25\%) against hatching of juveniles. Cell-free culture filtrates significantly reduced $(P<0.001)$ the hatching of $M$. javanica juveniles compared to controls. After 96 $\mathrm{h}$ of exposure B.t isolates at $5 \%$ concentration showed varied response on hatching of juveniles. B.t-64 and B.t-16 treated plants showed minimum hatching of juveniles, i.e. $19.3 \%$ and $20.48 \%$, respectively. Other B.t isolates caused $28-57 \%$ hatching of juveniles as compared to controls where $67.5 \%$ egg hatching was recorded (Fig.1A). At $25 \%$ ex- 

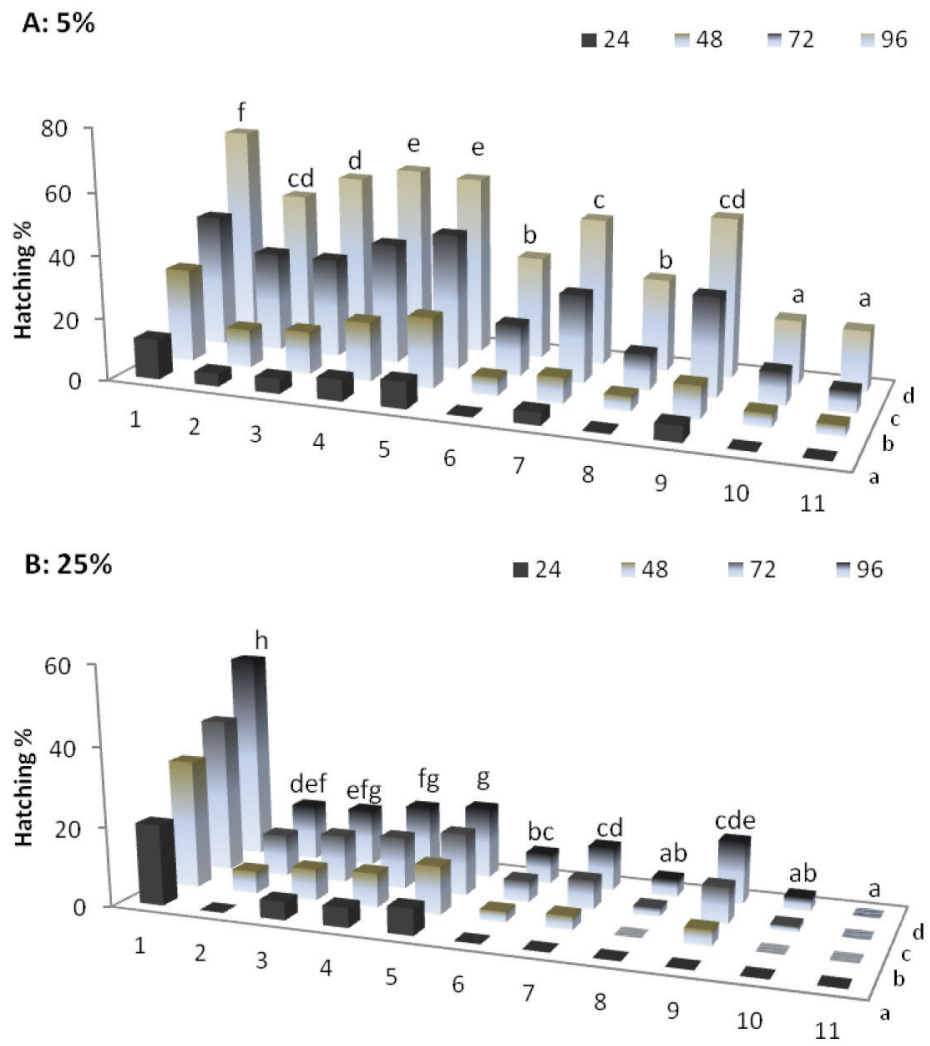

Fig.1. Effect of aqueous extract of B.t isolates at 5 (A) and 25\% (B) concentrations on hatching of J2 of root-knot nematodes. Treatments: $1=$ Control, $2=$ B.t-6, $3=$ B.t-7, $4=$ B.t-8, $5=$ B.t-9, $6=$ B.t-10, $7=$ B.t-13, $8=$ B.t-14, $9=$ B.t-15, $10=$ B.t-16, $11=$ B.t- 64

Treatments and time bars with same letters are not significantly different from each other according toTukey's HSD. Hatching \% was observed after 24, 48, 72 and 96 hours of exposure.

Each bar comprise mean of six replicates.

tract concentration, all the bacterial isolates significantly $(P<0.001)$ reduced the hatching percentages. However B.t-64 treated plants showed $100 \%$ reduction in hatching of juveniles, followed by B.t-16 and B.t-14 as compared to untreated controls (52.9\%) (Fig. 1 B).

\section{Mortality of root-knot nematodes}

Two concentrations ( 5 and $25 \%$ ) of the cell free culture filtrate were assessed to determine the mortality of $\mathrm{J} 2$ at 24, 48, 72 and $96 \mathrm{~h}$. Most of B.t isolates used in this study caused significant $(P<0.001)$ increase in mortality of $\mathrm{J} 2$ of root-knot nematode with respect to time. At 5\% concentration, some bacterial isolates, including B.t-64 significantly increased the mortality of $\mathrm{J} 2$ by $75 \%$, followed by B.t-14 (66\%) and B.t-16 (65\%) after $96 \mathrm{~h}$ of exposure $(P<0.001)$ (Fig. 2A). Mortality response at $25 \%$ concentration increased significantly $(P<0.001)$ with respect to time. Maximum mortality of $\mathrm{J} 2(81.7 \%)$ 
was observed for B.t-64 treated plants followed by B.t-16 (64.3\%) and B.t-14 (50.5\%) as compared to controls that showed $12 \%$ mortality. Application of other B.t isolates resulted in mortality percentages of $\mathrm{J} 2$ ranged between 13 to $33 \%$ (Fig. 2B).

\section{Greenhouse studies}

Shoot height of okra was significantly enhanced in soil drench treatments with B.t. isolates compared to controls. Maximum shoot height of $28 \mathrm{~cm}$ was recorded in plants treated with B.t-13, followed by B.t-64 $(25 \mathrm{~cm})$. B.t-10 $(2.27 \mathrm{~g})$, B.t-6 (2.2 g) and B.t-64 $(2.2 \mathrm{~g})$ showed higher shoot weights compared to untreated controls (Fig. 3A and C).

$$
\text { A: } 5 \% \quad \square 24 \quad \square 8 \quad-72 \quad \square 96
$$

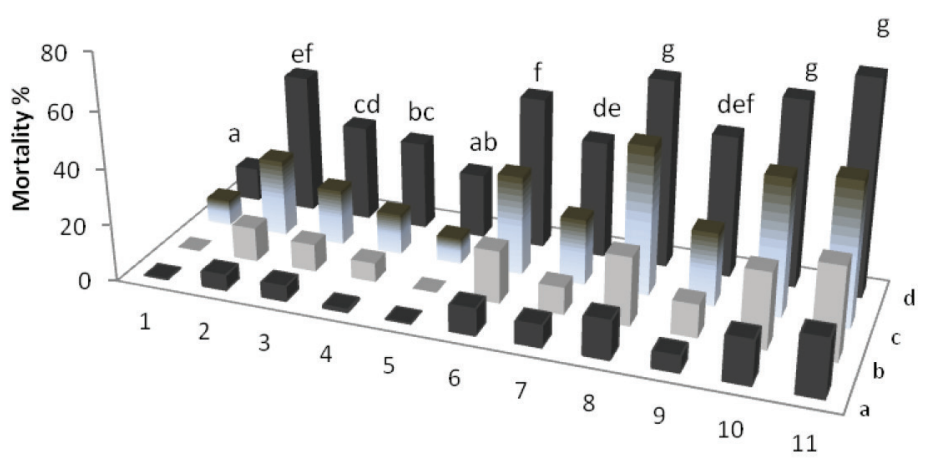

$$
\text { B: } 25 \% \quad \square 24 \quad \square 48 \quad-72 \quad \square 96
$$

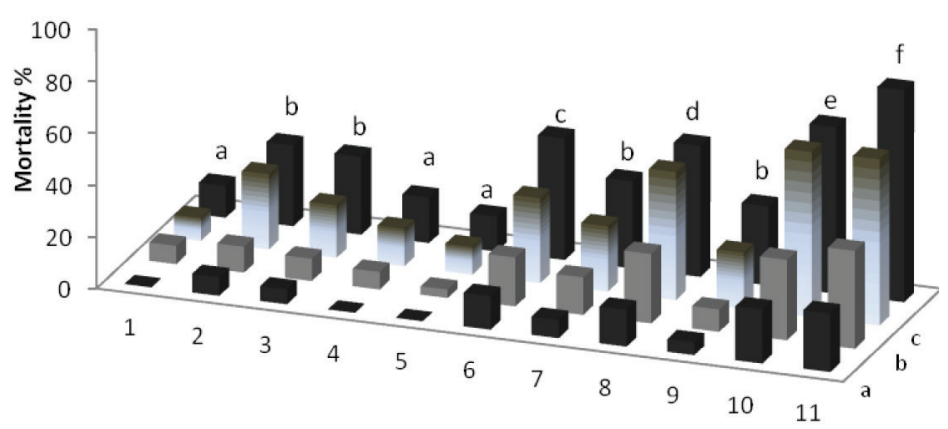

Fig. 2. Effect of aqueous extract of B.t isolates at 5 (A) and $25 \%$ (B) concentration on mortality of J2 of root- knot nematodes. Treatments: $1=$ Control, $2=$ B.t-6, $3=$ B.t-7, $4=$ B.t-8, $5=$ B.t-9, $6=$ B.t-10, $7=$ B.t-13, $8=$ B.t-14, $9=$ B.t-15, $10=$ B.t-16, $11=$ B.t -64

Treatments and time bars with same letters are not significantly different from each other according toTukey's HSD. Mortality \% was observed after 24, 48, 72 and 96 hours of exposure.

Each bar comprise mean of six replicates. 
A significant increase in root length was observed in plants treated by B.t-64 and B.t-14 $(17$ and $15 \mathrm{~cm})$, i.e. 112.5 , and $88 \%$ increase compared to non-treated control $(8 \mathrm{~cm})$. Root weight also significantly increased following soil drench with B.t isolates. B.t16 and B.t-14 treatments resulted in higher root weights compared to other treatments (Fig. 3B and D).

Number of galls/root system was greatly reduced in B.t-64, B.t-6 and B.t-14 treated plants $(28,39$, and 40 galls/root system), compared to untreated controls (94 galls/root system) (Fig. 4A). B.t-13, B.t-6 and B.t-16 showed 46\% lower egg mass formation in roots as compared to controls (Fig. 4B). The least number of eggs/egg mass was counted in B.t-64-treated plants, which was $42 \%$ lower than the control. B.t-16 and B.t-16 treatments also resulted in prominent decline in the number of eggs/egg mass (Fig. 4C). Soil drenched with most of the B.t isolates significantly reduced nematode population in the soil. B.t-64 and B.t-16 treated plants exhibited 652 and 672 nematodes/200 g soil, which is 43 and $41 \%$ lower than controls, respectively (Fig. 4D).

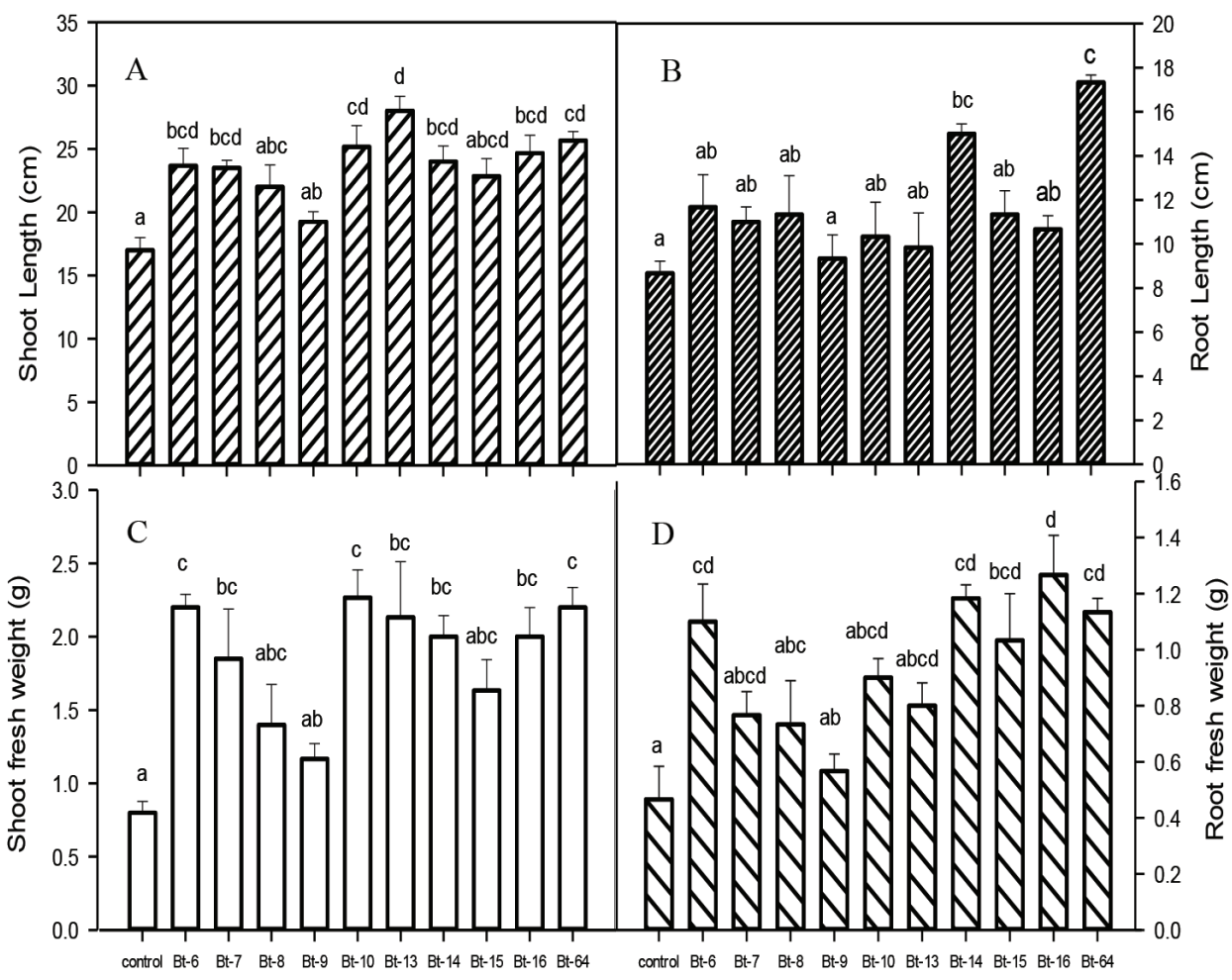

Fig. 3. Effects of Bacillus thuringiensis isolates on growth of okra under greenhouse conditions. Treatment bars with same letters are not significantly different from each other according to Tukey's HSD. 

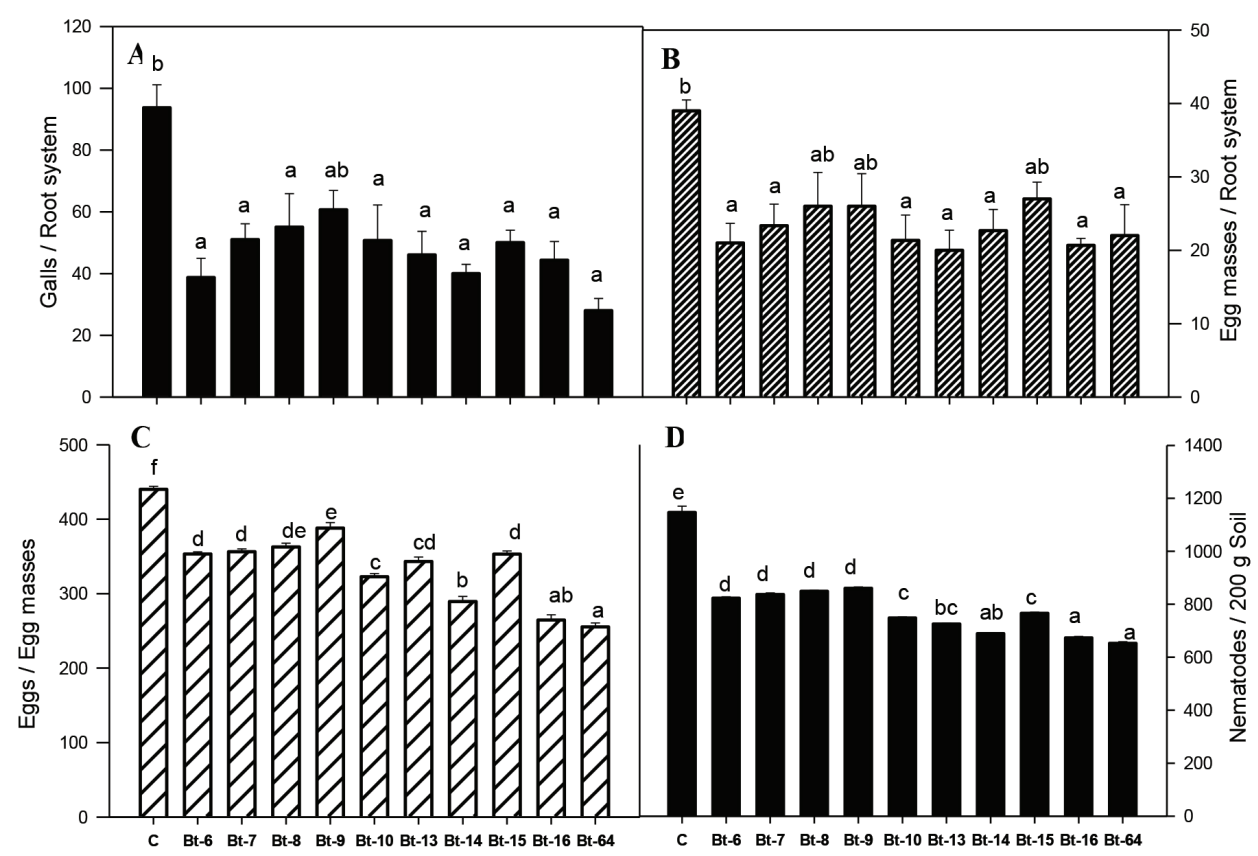

Fig. 4. Effects of Bacillus thuringiensis isolates on nematode parasitism in okra under greenhouse conditions.

Treatment bars with same letters are not significantly different from each other according to Tukey's HSD.

\section{Field studies}

Shoot height significantly increased in all tested B.t isolates under field conditions. B.t-64 and Bt-14 treated plants exhibited $61 \mathrm{~cm}$ shoot height, which was $28 \%$ higher as compared to control $(47.8 \mathrm{~cm})$ (Fig. 5A). Shoot weights increased in B.t-14 and B.t-64 treated plants, i.e. 19 and 10\% higher, respectively than the controls. However, reduction in shoot weight was recorded in B.t-16 treated plants by $22 \%$ (Fig. 5B). Similarly, root length was enhanced in Bt-64 and B.t-14 treated plants and declined in Bt-16 treated plants compared to untreated controls (Fig. 5C). Varied root weights were recorded in different treatments, while root weight significantly improved in B.t-14 treated plants, whereas, in B.t-64 and B.t-16 treated plants a decline was recorded (Fig. 5D).

Number of galls/root system was significantly $(P<0.05)$ reduced in all the B.t-treated plants. However, B.t-16 and B.t-64 treated plants exhibited the least number of galls i.e. 32\% lower than the non-treated controls (Fig. 6A). Soil drenched with B.t isolates significantly reduced $(P<0.001)$ egg masses/root system. B.t-64 and B.t-16 treatments resulted in 25 and 29 egg masses in roots, followed by B.t-14 showing 30 egg masses/root system compared to untreated controls showing 36 egg masses/root system (Fig. 6B). Eggs/egg mass were significantly $(P<0.001)$ reduced in soil drenched with B.t isolates treatments with B.t-64, B.t-14 and B.t-16 isolates resulted in 324, 506 and 517 eggs/egg mass, respectively, i.e. 56, 33 and $31 \%$ lower as compared to non-treated 


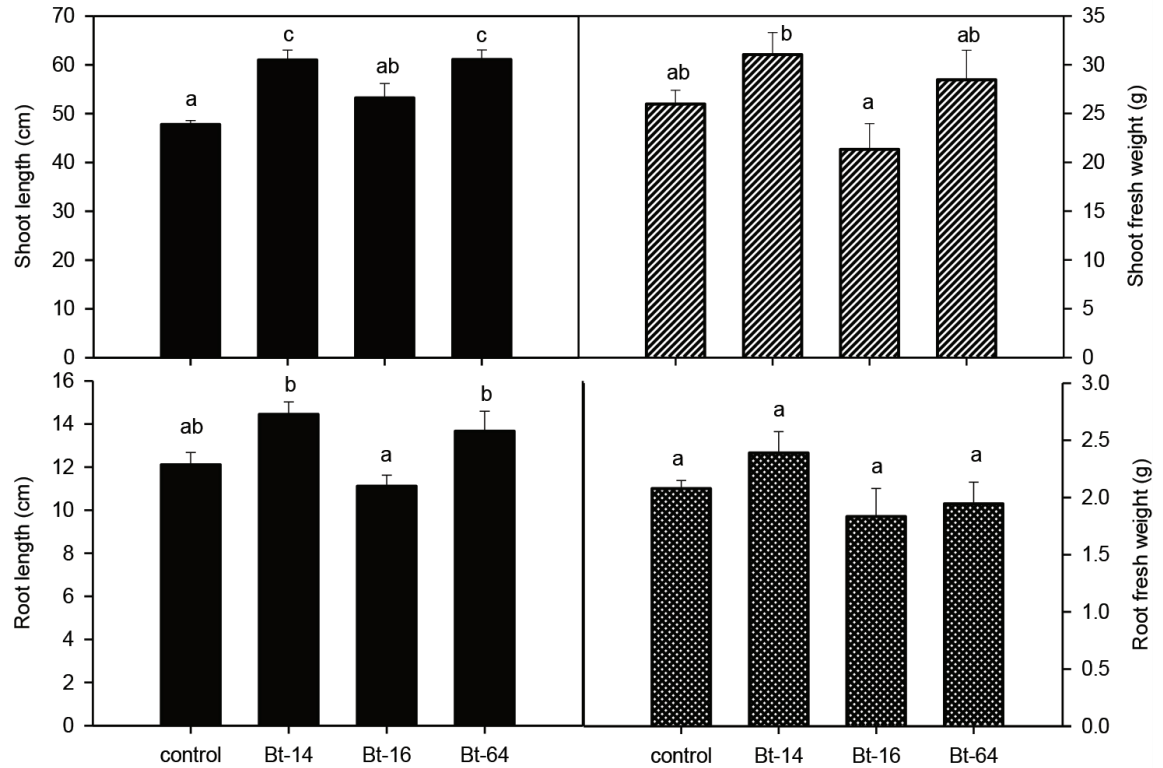

Fig. 5. Effects of Bacillus thuringiensis isolates on growth of okra under field conditions.

Treatment bars with same letters are not significantly different from each other according to Tukey's HSD.

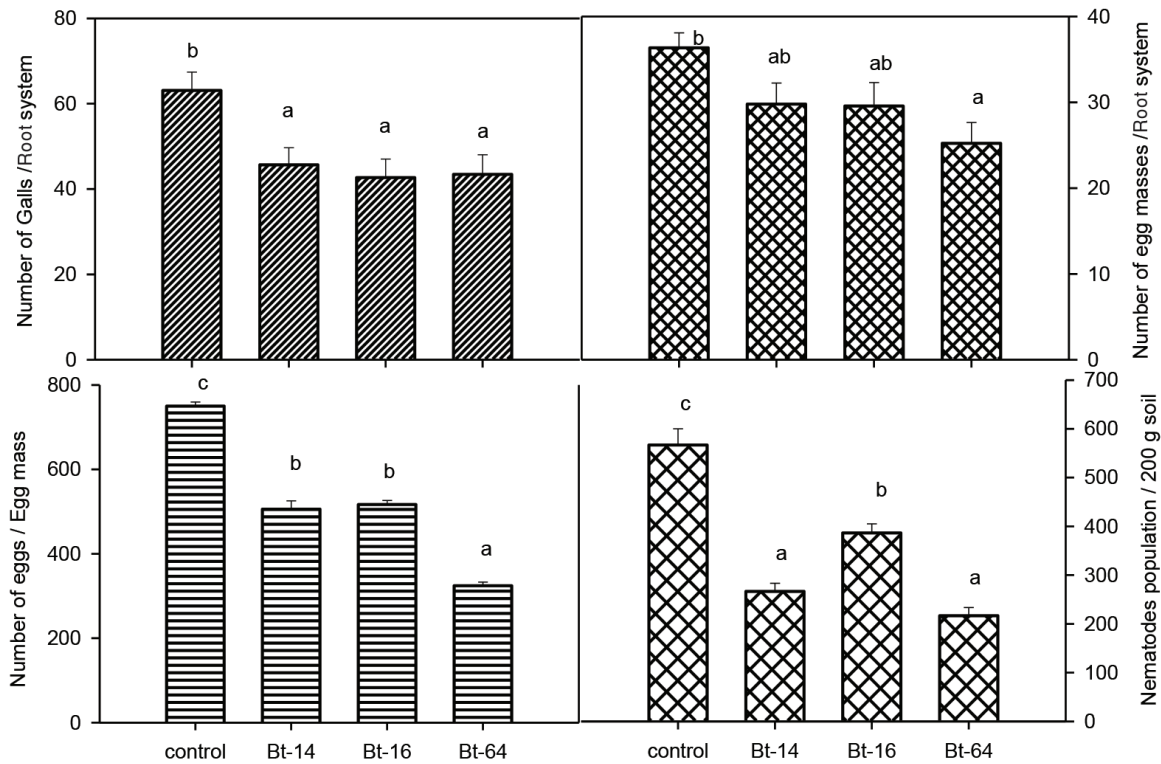

Fig. 6. Effects of Bacillus thuringiensis isolates on nematode parasitism in okra under field conditions.

Treatment bars with same letters are not significantly different from each other according to Tukey's HSD. 
control (750 eggs/egg mass) (Fig. 6C). Soil drench application of B.t isolates significantly $(P<0.001)$ reduced nematode population/200 g soil. B.t-64, B.t-14 and B.t-16 caused 62,44 and $35 \%$ reduction, respectively, in nematode population/200 g soil compared to controls (Fig. 6D).

\section{Discussion}

Studies on B.t isolates showed reduced hatching of J2 and caused significant mortality of juveniles of M. javanica. In a previous study, the larvicidal potential of Bacillus cereus was observed with its collagenolytic/proteolytic enzyme (Sela et al., 1998) exerting its effect on the cuticle of M. javanica. Proteases from bacteria (Bacillus species) (Lian et al., 2007) and fungi (Monacrosporium microscaphoides) were also identified as potential nematicidal agents (Wang et al., 2006). It is an established fact that bacteria produce proteases which cause lysis of proteinaceous metabolites. The actual mode of action of ammonia is still unclear (Oka, 2010). Cell free B.t extract reduced hatching of juveniles and caused substantial mortality to $\mathrm{J} 2$ of root-knot nematodes at $50 \%$ concentration (Khan et al., 2010). However, in the present study, similar results were obtained at lower concentrations (5 and $25 \%)$ of cell free extracts of B.t. isolates.

Some B.t isolates, including B.t-64, B.t-16 and B.t-14 in greenhouse and field studies were found effective in enhancing plant growth and reducing root-knot nematode parasitism. These B.t. isolates were previously found to increase plant growth and reduce nematode parasitism in okra and mung bean when applied as a seed treatment (Khan et al., 2010). However, a previous study suggested that application of Bacillus species by different methods significantly altered the penetration of bacteria in plants. Further, it was recorded that soil drench method proved more effective than the seed treatment (Bressan and Borges, 2004).

B. thuringiensis isolated from surface sterilized nodules of soybean plant improved plant growth and enhanced the ability of the nodulation capacity of nodule forming bacteria, hence suggesting the potential as plant-growth-promoting bacteria (PGPR) (Bai et al., 2002). Shishido et al. (1996) observed an appreciable increase in plant growth of pine and spruce after the application of three strains of Bacillus polymyxa. Some volatile compounds from Bacillus species have the ability to trigger the greatest level of growth promotion in Arabidopsis thaliana (Ryu et al., 2003). The ability of bacteria to colonize root surface is considered an important feature in the soil for plant growth promoting efficiency. Previously, De-Bashan et al. (2010) reported that Bacillus pumilus ES4 effectively colonized root tips and root elongation areas and altered the bacterial community. Reduced efficiency of $B$. thuringiensis under field conditions may due to competition with other rhizosphere inhabiting microorganisms for space and nutrition. Further, moisture and temperature extremes greatly affect the cell count of B.t isolates in soil (Khan et al., 2011). However, endospore forming ability is a unique feature helping Bacillus species to survive in soil for a long period of time. It was reported that sporogenic strains of B.t rapidly formed spores and survive till 20 days in soil (Vilas-Bôas et al., 2000). Treatments with Bacillus species enhance production of defense related biochemicals with improved growth of solanaceous plants in greenhouse and field conditions (Akram et al., 2013; Abbasi et al., 2014). Some other reports suggest that Bacillus species influence the effec- 
tiveness of arbuscular mycorrhiza and when B. pumilus was co-inoculated with Glomus deserticola improved dry matter production in Medicago sativa (Medina et al., 2003). Formulation of Bacillus firmus when applied to tomato plants increased plant height and biomass by 71 and $50 \%$ in greenhouse, while in the field trials, plant showed 29-31\% higher shoot height and 20-24\% greater plant weight (Terefe et al., 2009). Root-knot nematode parasitism decreased with the application of B.t isolates in soil. Severity of parasitism was recorded in terms of gall and egg masses/root system, number of eggs per egg mass and nematode population in the rhizosphere. Previous reports demonstrated that B. thuringiensis soil drench reduced galling of Meloidogyne species on roots of tomato by 51-59\% (Khyami-Horani and Al-Banna, 2006). Terefe et al. (2009) worked on B. firmus formulation against root-knot nematode infestation in tomato. They reported reduced gall formation, nematode population and number of eggs under greenhouse and field conditions. Similarly, Sharma (1994) achieved reduced parasitism of M. incognita in barley following the application of B. thuringiensis. A similar study by Keren-Zur et al. (2000) showed reduced root-knot disease in cucumber and tomato following the B. firmus formulation in greenhouse and field trials. Lesser root fresh weight in control plants having a greater number of galls probably due to the small sized galls. The size of the galls varies in different plant species due to many factors, including variation in the size of giant cell, number of giant cells per feeding site and number of nuclei per giant cell (Vovlas et al., 2005). Sometimes more than one females are closely found in roots in a single gall which further increases the size of the galls. However, we observed fewer egg masses compared to galls indicating that not more than one female per galls. Root colonizing bacteria may alter plant gene expression in roots that further affecting root exudation (Van Loon, 2007). However, sometimes plants exhibit induced systemic resistance without expressing any changes in genes after the application of rhizobacteria (Van Loon and Bakker, 2007). Some studies have been conducted on transgenically expressed cry protein genes in roots of tomato to suppress the root-knot nematode parasitism (Li et al., 2007; Li et al., 2008). The study leads us to suggest that application of B.t isolates was found to be more effective as compared to previous studies (Khan et al., 2010), where B.t isolates applied on seeds before germination against root-knot nematodes. In conclusions, the study demonstrated that B.t isolates adopted to rhizosphere conditions where isolates directly affected root-knot nematodes. Reduced juvenile population in the rhizosphere and reduced nematode parasitism thereby showed positive effects on plant growth. However, the biocontrol potential varied in B.t isolates under greenhouse and field conditions. More studies needed to find out activities of some of the tested isolates, including B.t-64 and B.t-16. Both isolates demonstrated better results compared to other tested isolates.

\section{Acknowledgement}

This work is conducted under the research project (20-683/r \& D/06) funded by Higher Education Commission, Pakistan. 


\section{Literature}

Abbasi, M. W., Ahmed, N., Zaki, M. J., Shuakat, S. S. and Khan, D. (2014): Potential of Bacillus species against Meloidogyne javanica parasitizing eggplant (Solanum melongena L.) and induced biochemical changes. Plant Soil 375, 159-173.

Adam, M., Heuer, H. and Hallmann, J. (2014): Bacterial antagonists of fungal pathogens also control root-knot nematodes by induced systemic resistance of tomato plants. PloS one 9, e90402.

Akram, W., Anjum, T., Ali, B. and Ahmad, A. (2013): Screening of native Bacillus strains to induce systemic resistance in tomato plants against fusarium wilt in split root system and its field applications. Int. J. Agric. Biol. 15, 1289-1294.

Bai, Y., D'Aoust, F., Smith, D. L. and Driscoll, B. T. (2002): Isolation of plant-growth-promoting Bacillus strains from soybean root nodules. Can. J. Microbiol. 48, 230-238.

Bernhard, K., Jarrett, P., Meadows, M., Butt, J., Ellis, D., Roberts, G., Pauli, S., Rodgers, P. and Burges, H. (1997): Natural isolates of Bacillus thuringiensis: worldwide distribution, characterization, and activity against insect pests. J. Invert. Pathol. 70, 59-68.

Bottjer, K. P., Bone, L. W. and Gill, S. S. (1985): Nematoda: susceptibility of the egg to Bacillus thuringiensis toxins. Exp. Parasitol. 60, 239-244.

Bressan, W. and Borges, M. T. (2004): Delivery methods for introducing endophytic bacteria into maize. BioControl. 49, 315-322.

Cayrol, J. C., Djian, C. and Pijarowski, L. (1989): Study of the nematicidal properties of the culture filtrate of the nematophagous fungus Paecilomyces lilacinus. Revue de Nematol. 12, 331-336.

Chen, X. H., Koumoutsi, A., Scholz, R., Eisenreich, A., Schneider, K., Heinemeyer, I., Morgenstern, B., Voss, B., Hess, W. R. and Reva, O. (2007): Comparative analysis of the complete genome sequence of the plant growth-promoting bacterium Bacillus amyloliquefaciens FZB42. Nat. Biotechnol. 25, 1007-1014.

Daykin, M. and Hussey, R. (1985): Staining and histopathological techniques in nematology. In: K. R. Barker, C. C. Carter and J. N. Sasser (eds): An Advanced Treatise on Meloidogyne. Vol. II. Methodology, North Carolina State University Graphics, pp. 39-48.

De-Bashan, L. E., Hernandez, J. P., Bashan, Y. and Maier, R. M. (2010): Bacillus pumilus ES4: candidate plant growth-promoting bacterium to enhance establishment of plants in mine tailings. Environ. Exper. Bot. $69,343-352$.

Dhawan, S., Kaur, S. and Singh, A. (2004): Effect of Bacillus thuringiensis on the mortality of root-knot nematode, Meloidogyne incognita. Indian J. Nematol. 34, 98-99.

Flor-Peregrín, E., Azcón, R., Martos, V., Verdejo-Lucas, S. and Talavera, M. (2014): Effects of dual inoculation of mycorrhiza and endophytic, rhizospheric or parasitic bacteria on the root-knot nematode disease of tomato. Biocontrol Sci. Techn. 24, 1122-1136.

Gomez, K. A. and Gomez, A. A. (1984): Statistical Procedures for Agricultural Research. John Wiley and Sons, $2^{\text {nd }}$ ed. pp. 1-680.

Hill, K. K., Ticknor, L. O., Okinaka, R. T., Asay, M., Blair, H., Bliss, K. A., Laker, M., Pardington, P. E., Richardson, A. P. and Tonks, M. (2004): Fluorescent amplified fragment length polymorphism analysis of Bacillus anthracis, Bacillus cereus, and Bacillus thuringiensis isolates. Appl. Environ. Microbiol. 70, 1068-1080.

Hussain, M. A., Mukhtar, T., Kayani, M. Z., Aslam, M. N. and Haque, M. (2012): A survey of okra (Abelmoschus esculentus) in the Punjab province of Pakistan for the determination of prevalence, incidence and severity of root-knot disease caused by Meloidogyne spp. Pak. J. Bot. 44, 2071-2075.

Hussey, R. S. and Barker, K. R. (1973): A comparison of methods of collecting inocula of Meloidogyne spp. including a new technique. Plant Disease Rep. 57, 1025-1028.

Keren-Zur, M., Antonov, J., Bercovitz, A., Feldman, K., Husid, A., Kenan, G., Marcov, N. and Rebhun, M. (2000): Bacillus firmus formulations for the safe control of root-knot nematodes. Proc. of the The BCPC Conference: Pests and Diseases. Vol. 1. Proc. of an International Conference held at the Brighton Hilton Metropole Hotel, Brighton, UK, 13-16 November 2000; British Crop Protection Council, pp. 47-52.

Khan, M. Q., Abbasi, M. W., Zaki, M. J. and Khan, S. A. (2010): Evaluation of Bacillus thuringiensis isolates against root-knot nematodes following seed application in okra and mungbean. Pak. J. Bot. 42, 2903-2910. 
Khan, M. Q., Zaki, M. J. and Khan, D. (2011): The influence of moisture and temperature on the survival of Bacillus thuringiensis Berliner in autoclaved soil. Int. J. Biol. Biotechn. 8, 225-232.

Khyami-Horani, H. and Al-Banna, L. (2006): Efficacy of Bacillus thuringiensis jordanica against Meloidogyne javanica infecting tomato. Phytopath. Medit. 45, 153-157.

Li, B., Xie, G., Soad, A. and Coosemans, J. (2005): Suppression of Meloidogyne javanica by antagonistic and plant growth-promoting rhizobacteria. J. Zhejiang Univ. Sci. 6, 496-501.

Li, X., Wei, J. Z., Tan, A. and Aroian, R. V. (2007): Resistance to root-knot nematode in tomato roots expressing a nematicidal Bacillus thuringiensis crystal protein. Plant Biotech. J. 5, 455-464.

Li, X. Q., Tan, A., Voegtline, M., Bekele, S., Chen, C. S. and Aroian, R. V. (2008): Expression of Cry5B protein from Bacillus thuringiensis in plant roots confers resistance to root-knot nematode. Biol. Control. 47, 97-102.

Lian, L., Tian, B., Xiong, R., Zhu, M., Xu, J. and Zhang, K. (2007): Proteases from Bacillus: a new insight into the mechanism of action for rhizobacterial suppression of nematode populations. Lett. Appl. Microbiol. 45, 262-269.

Luc, M., Sikora, R. A. and Bridge, J. (2005): Plant Parasitic Nematodes in Subtropical and Tropical Agriculture. 2nd ed., Cabi Publishing, Wallingford, U.K., pp. 1-896.

Medina, A., Probanza, A., Mañero, F. G. and Azcón, R. (2003): Interactions of arbuscular-mycorrhizal fungi and Bacillus strains and their effects on plant growth, microbial rhizosphere activity (thymidine and leucine incorporation) and fungal biomass (ergosterol and chitin). Appl. Soil Ecol. 22, 15-28.

Mizuki, E., Ichimatsu, T., Hwang, S. H., Park, Y., Saitoh, H., Higuchi, K. and Ohba, M. (1999): Ubiquity of Bacillus thuringiensis on phylloplanes of arboreous and herbaceous plants in Japan. J. Appl. Microbiol. 86, 979-984.

Mohammed, S., El-Saedy, M. A., Enan, M. R., Ibrahim, N. E., Ghareeb, A. and Moustafa, S. A. (2008): Biocontrol efficiency of Bacillus thuringiensis toxins against root-knot nematode, Meloidogyne incognita. J. Cell Mol. Biol. 7, 57-66.

Oka, Y. (2010): Mechanisms of nematode suppression by organic soil amendments: a review. Appl. Soil Ecol. 44, 101-115.

Oostendorp, M. and Sikora, R. (1990): In vitro interrelationships between rhizosphere bacteria and Heterodera schachtii. Revue de Nématol. 13, 269-274.

Payne, J. M. (1992): US Patent No. 5,151,363. Washington, DC: U.S. Patent and Trademark Office.

Ryu, C. M., Farag, M. A., Hu, C. H., Reddy, M. S., Wei, H. X., Paré, P. W. and Kloepper, J. W. (2003): Bacterial volatiles promote growth in Arabidopsis. Proc. Natl. Acad. Sci. 100, 4927-4932.

Sela, S., Schickler, H., Chet, I. and Spiegel Y. (1998): Purification and characterization of a Bacillus cereus collagenolytic/proteolytic enzyme and its effect on Meloidogyne javanica cuticular proteins. Eur. J. Plant Pathol. 104, 59-67.

Sharma, R. D. (1994): Bacillus thuringiensis: A biocontrol agent of Meloidogyne incognita on barley. Nematol. Bras. 18, 79-84.

Shishido, M., Petersen, D. J., Massicotte, H. B. and Chanway, C. P. (1996): Pine and spruce seedling growth and mycorrhizal infection after inoculation with plant growth promoting Pseudomonas strains. FEMS Microbiol. Ecol. 21, 109-119.

Siddiqui, Z. and Mahmood, I. (1999): Role of bacteria in the management of plant parasitic nematodes: a review. Biores. Techn. 69, 167-179.

Taylor, D. P. and Netscher. C. (1974): An improved technique for preparing perennial pattern of Meloidogyne spp. Nematol. 20, 268.

Terefe, M., Tefera, T. and Sakhuja, P. (2009): Effect of a formulation of Bacillus firmus on root-knot nematode Meloidogyne incognita infestation and the growth of tomato plants in the greenhouse and nursery. J. Invert. Pathol. 100, 94-99.

Townshend, J. (1962): An examination of the efficiency of the Cobb decanting and sieving method. Nematologica 8, 293-300.

Van-Loon, L. (2007): Plant responses to plant growth-promoting rhizobacteria. Eur. J. Plant Pathol. 119, $243-254$.

Van-Loon, L. and Bakker, P. A. H. M. (2007): Root-associated bacteria inducing systemic resistance. In: S. S. Gnanamanickam (ed.): Plant-Associated Bacteria. Springer, pp. 269-316. 
Vilas-Bôas, G. T. and Lemos, M. V. F. (2004): Diversity of cry genes and genetic characterization of Bacillus thuringiensis isolated from Brazil. Can. J. Microbiol. 50, 605-613.

Vilas-Bôas, L. A., Vilas-Bôas, G. F., Saridakis, H. O., Lemos, M. V. F., Lereclu, D. and Arantes, O. M. (2000): Survival and conjugation of Bacillus thuringiensis in a soil microcosm. FEMS Microbiol. Ecol. 31, 255-259.

Vovlas, N., Rapoport, H. F., Jiménez-Díaz, R. M. and Castillo, P. (2005): Differences in feeding sites induced by root-knot nematodes, Meloidogyne spp., in chickpea. Phytopathol. 95, 368-375.

Wang, M., Yang, J. and Zhang, K. Q. (2006): Characterization of an extracellular protease and its cDNA from the nematode-trapping fungus Monacrosporium microscaphoides. Can. J. Microbiol. 52, 130-139.

Wei, J. Z., Hale, K., Carta, L., Platzer, E., Wong, C., Fang, S. C. and Aroian, R. V. (2003): Bacillus thuringiensis crystal proteins that target nematodes. Proc. Natl. Acad. Sci. 100, 2760-2765.

Yap, C. A. (2013): Screening for nematicidal activities of Bacillus species against root knot nematode (Meloidogyne incognita). Am. J. Exp. Agri. 3, 794-805.

Zuckerman, B. M., Dicklow, M. B. and Acosta, N. (1993): A strain of Bacillus thuringiensis for the control of plant-parasitic nematodes. Biocontrol Sci. Techn. 3, 41-46. 